\title{
Efektivitas Penerapan Penggunaan Laboratorium Riil Dalam Tatanan Pembelajaran Berbasis Masalah Terhadap Keterampilan Proses Sains Siswa Kelas XI SMA Negeri 6 Pematangsiantar
}

\author{
Sumarny Tridelpina Purba (1), Thiur Dianti Siboro (2) \\ Program Studi Pendidikan Biologi Universitas Simalungun \\ Sumarny84.purba@gmail.com, iyun.siboro@yahoo.co.id
}

\begin{abstract}
ABSTRAK
Penelitian ini bertujuan untuk mengetahui evektivitas penerapan penggunaan laboratorium riil dalam tatanan pembelajaran berbasis masalah terhadap keterampilan proses sains siswa di SMA Negeri 6 Pematangsiantar. Metode penelitian yang digunakan metode penelitian tindakan kelas yang mencakup Siklus I dan Siklus II dengan menggunakan Laboratorium Riil dalam tatanan pembelajaran berbasis masalah. Pengumpulan data terdiri dari lembar observasi, LKS, soal pretest, dan soal postest. Teknik pengambilan data adalah dengan observasi, dan tes. Dari hasil penelitian diperoleh bahwa keterampilan proses sains yang diperoleh pada penelitian ini, berada dikategori "cukup" dan "baik". Kemudian rata-rata peningkatan hasil belajar dengan menggunakan model pebelajaran berbasis masalah yang memiliki rentang perbedaan yang besar dari siklus I sampai siklus II dimana dapat dikategorikan dari sedang menjadi tinggi. Dari hasil penelitian di atas, dapat disimpulkan bahwa pembelajaran biologi dengan penerapan penggunaan laboratorium rill dalam tatanan model pembelajaran berbasis masalah mampu meningkatkan keterampilan proses sains siswa pada kelas XI SMA Negeri 6 Pematangsiantar.
\end{abstract}

Kata Kunci : Laboratorium, Pembelajaran Berbasis Masalah, Keterampilan Proses Sains

\begin{abstract}
This study aims to determine the effectiveness of the application of the use of real laboratories in problembased learning arrangements on the science process skills of students at SMA Negeri 6 Pematangsiantar. The research method used is a classroom action research method that includes Cycle I and Cycle II by using a Real Laboratory in a problem-based learning setting. Data collection consisted of observation sheets, worksheets, pretest questions, and postest questions. Data collection techniques are by observation, and tests. The results showed that the science process skills obtained in this study were in the "fair" and "good" categories. Then the average increase in learning outcomes using a problem-based learning model that has a large range of differences from cycle I to cycle II which can be categorized from moderate to high. From the results of the above research, it can be concluded that biology learning by applying the use of real laboratories in a problembased learning model can improve students' science process skills in class XI SMA Negeri 6 Pematangsiantar..
\end{abstract}

Keywords : Laboratory, Problem Based Learning, Science Process Skills 
Tridelpina Purba S, Dianti Siboro T : Efektivitas Penerapan Penggunaan Laboratorium Riil Dalam Tatanan Pembelajaran Berbasis Masalah Terhadap Keterampilan Proses Sains Siswa Kelas XI SMA Negeri 6 Pematangsiantar

\section{PENDAHULUAN}

\section{Latar Belakang}

Masalah yang dihadapi dalam dunia pendidikan Indonesia saat ini adalah lemahnya proses pembelajaran. Dalam proses pembelajaran peserta didik didorong untuk mengembangkan kemampuan berpikir. Proses pembelajaran di dalam kelas diarahkan kemampuan peserta didik untuk mengingat berbagai informasi tanpa dituntut untuk memahami informasi yang diingatnya itu untuk menghubungkannya dengan kehidupan sehari-hari (Sanjaya,2006). Mata pelajaran Biologi menekankan pada pemberian pengalaman belajar secara langsung melalui penggunaan dan pengembangan keterampilan di bidang sains, maka pembelajaran yang paling sesuai adalah dengan metode demonstrasi atau eksperimen. Melalui metode demonstrasi atau eksperimen siswa secara langsung dapat mengalami proses dalam belajar biologi, mampu menumbuhkan kemampuan berfikir, bekerja serta mengkomunikasikannya sebagai aspek penting kecakapan hidup. Banyaknya materi pelajaran biologi yang berkaitan langsung dengan kehidupan sehari-hari dan lingkungan, namun dalam proses belajar mengajar guru dan siswa tidak mungkin menyampaikannya dengan obyek yang sebenarnya, dengan alasan pertimbangan biaya, resiko yang mungkin terjadi dan waktu yang tidak memungkinkan. Pembelajaran biologi sebaiknya dapat dimodivikasi dengan memberikan contoh permasalahan yang ada dilingkungan sekitar, misalnya pencemaran lingkungan adalah berubahnya tatanan lingkungan oleh kegiatan manusia ataupun proses alam yang menyebabkan kualitas lingkungan turun sampai ketingkat tertentu sehingga lingkungan tidak dapat berfungsi lagi sesuai dengan peruntukannya. Menurut Bangun (2012) tujuan strategi pembelajaran problem based learning adalah untuk mencapai pembelajaran yang efektif dalam mengembangkan pengetahuan, pemahaman dan kemampuan berpikir kritis untuk memecahkan masalah. Dalam startegi pembelajaran problem based learning siswa akan terlibat secara langsung dan akan membuat siswa lebih memahami materi dan lebih mengingat.

\section{Perumusan Masalah}

Berdasarkan uraian latar belakang, maka yang menjadi rumusan masalah adalah

1. Apakah terdapat pengaruh penerapan penggunaan laboratorium riil dalam tatanan pembelajaran berbasis masalah terhadap keterampilan proses sains siswa di SMA Negeri 6 Pematangsiantar?

2. Apakah terdapat perbedaan keefektifan antara penerapan penggunaan laboratorium riil dalam tatanan pembelajaran berbasis masalah ditinjau dari keterampilan proses sains siswa di SMA Negeri 6 Pematangsiantar?

\section{Tujuan Penelitian}

Penelitian ini bertujuan yaitu :

1. Untuk mengetahui pengaruh penerapan penggunaan laboratorium riil dalam tatanan pembelajaran berbasis masalah terhadap keterampilan proses sains siswa di SMA Negeri 6 Pematangsiantar?

2. Untuk mengetahui apakah terdapat perbedaan keefektifan antara penerapan penggunaan laboratorium riil dalam tatanan pembelajaran berbasis masalah ditinjau dari keterampilan proses sains siswa di SMA Negeri 6 Pematangsiantar? 
Tridelpina Purba S, Dianti Siboro T : Efektivitas Penerapan Penggunaan Laboratorium Riil Dalam Tatanan Pembelajaran Berbasis Masalah Terhadap Keterampilan Proses Sains Siswa Kelas XI SMA Negeri 6 Pematangsiantar

\section{Manfaat Penelitian}

Manfaat penelitian ini bagi pembelajaran yang dilakukan dengan memunculkan permasalahan diharapkan dapat meningkatkan hasil belajar siswa, dan kemampuan berpikir kritis. Solusi yang dapat digunakan untuk mengatasi permasalahan ini adalah merancang suatu penelitian dengan menggunakan strategi pembelajaran yang lebih tepat. Strategi pembelajaran ini diharapkan dapat meningkatkan keterampilan proses sains siswa

\section{METODE PENELITIAN}

\section{Subjek Penelitian}

Subjek dalam penelitian ini adalah semua siswa kelas XI IPA 1 SMA Negeri 6 Pematangsiantar tahun pelajaran 2019/2020 yang berjumlah 32 siswa

\section{Jenis Penelitian dan Sumber Data}

Jenis penelitian ini adalah penelitian tindakan kelas dengan menggunakan model pembelajaran yang menggunakan Laboratorium Riil dalam tatanan pembelajaran berbasis masalah. Jenis data yang digunakan dalam penelitian ini adalah data utama dan data pendukung. Data utama yaitu data nilai pretes-postes dan data pendukung yaitu data nilai sikap siswa selama mengikuti proses pembelajaran. Kedua jenis data bersumber dari seluruh subjek penelitian.

\section{Desain Penelitian}

Penelitian ini dilakukan dengan menggunakan metode penelitian tindakan kelas yang terbagi dengan dua siklus. Masing-masing siklus terdiri dari empat tahapan kegiatan yaitu tahapan perencanaan (planning), tindakan (action), observasi (observation), serta refleksi (reflection).

\section{Instrumen dan Uji Instrumen Instrumen Penelitian}

1. Instrumen penelitian.

Instrumen yang digunakan untuk menilai keterampilan proses sains adalah pretest-postest dan lembar observasi. Data Pretest dan Postest digunakan untuk mengukur hasil belajar siswa sedangkan lembar observasi pembelajaran ini digunakan untuk mengamati keterampilan proses sains siswa yang terjadi selama proses pembelajaran berlangsung.

2. Uji Instrumen Penelitian

Sebelum instrumen digunakan untuk penelitian terlebih dahulu instrumen diuji validitas dan reliabilitas.

a. Validitas Instrumen

Untuk menghitung validitas butir soal menurut (Sudjionono, $2011: 185$ ) adalah :1

$$
R_{x y}=\frac{N \sum x-\left(\sum x\right)\left(\sum y\right)}{\sqrt{\left\{N \sum x^{2}-\left(\sum x\right)^{2}\right\}\left\{N \sum y^{2}-\left(\sum y\right)^{2}\right\}}}
$$

\section{Keterangan rumus :}

$\mathrm{R}_{\mathrm{xy}}=$ koefisien validitas item

$\mathrm{x}=$ nilai untuk setiap item'

$\mathrm{y}=$ nilai total seluruh item

$\mathrm{n}=$ jumlah responden

Jika $\Gamma_{\mathrm{xy}}>\Gamma_{\text {tabel }}$ maka soal tersebut valid, sedangkan

Jika $\Gamma_{\mathrm{xy}}<\Gamma \mathrm{t}_{\text {abel }}$ maka soal tersebut tidak valid Jika menafsirkan keberadaan harga validitas tiap item, maka $\Gamma_{\mathrm{xy}}$ dikonsultasikan dengan harga produk moment dengan $\alpha=0.05$. Jika harga $\Gamma_{\mathrm{xy}}>\Gamma_{\text {tabel }}$ maka soal tersebut dikatakan valid.

b. Reliabilitas Instrumen 
Tridelpina Purba S, Dianti Siboro T : Efektivitas Penerapan Penggunaan Laboratorium Riil Dalam Tatanan Pembelajaran Berbasis Masalah Terhadap Keterampilan Proses Sains Siswa Kelas XI SMA Negeri 6 Pematangsiantar

Untuk menghitung koefisien reliabilitas menurut (Sudjiono, 2011:254) digunakan rumus Khuder Richardson 20 atau K-R 20 yaitu :

$$
r_{11}=\left(\frac{n}{n-1}\right)\left(\frac{s^{2} \sum p \cdot q}{s^{2}}\right)
$$

\section{Keterangan rumus}

$\mathrm{r}_{11}=$ Reliabilitas tes

$\mathrm{n}=$ Jumlah soal

$\mathrm{p}=$ proporsi jawaban yang benar

$\mathrm{s}^{2}=$ proporsi jawaban yang salah

$\sum_{\mathrm{pq}}=$ Jumlah perkalian $\mathrm{p}$ dan $\mathrm{q}$

\section{Dengan Kriteria}

Tabel 1. Kategori Relibilitas Tes

\begin{tabular}{|c|c|}
\hline Batasan Reliabilitas Tes & Kategori \\
\hline $0.00-0.21$ & sangat rendah \\
\hline $0.21-0.40$ & rendah \\
\hline $0.41-0.60$ & sedang \\
\hline $0.61-0.80$ & tinggi \\
\hline $0.81-1,00$ & Sangat tinggi \\
\hline
\end{tabular}

c. Tingkat Kesukaran Tes

Untuk mengetahui taraf kesukaran menurut Arikunto (2009) digunakan sebagai berikut:

$$
P=\frac{B}{J S}
$$

\section{Keterangan rumus :}

$\mathrm{P}=$ Indeks kesukaran tes

$\mathrm{B}=$ Jumlah subjek yang menjawab benar

$\mathrm{JS}=$ Jumlah seluruh subjek peserta tes

\section{Dengan Kriteria}

Tabel 2 Kategori Kesukaran Tes

\begin{tabular}{|c|c|}
\hline Batasan Kesukaran Tes & Kategori \\
\hline $\mathrm{P}: 0.00-0.30$ & Sukar \\
\hline $\mathrm{P}: 0.31-0.70$ & Sedang \\
\hline $\mathrm{P}: 0.71-1,00$ & Mudah \\
\hline
\end{tabular}

\section{Teknik Analisis Data}

Data yang didapat dan didikumpulkan kemudian dianalisis dengan menggunakan teknik analisis kuantitatif. Analisis kuantitatif yang digunakan yakni mendeskripsikan karaktersitik secara verbal tentang peningkatan hasil bejar siswa setelah diadakan tes. Sedangkan untuk data keterampilan proses sains diperoleh dari observasi pada siklus I dan siklus II.

Tabel 3 Kategori Hasil Belajar Siswa

\begin{tabular}{|c|c|}
\hline Rata-Rata & Kategori Hasil Belajar \\
\hline $90-100$ & Sangat Tinggi \\
\hline $75-89$ & Tinggi \\
\hline $55-74$ & Sedang \\
\hline
\end{tabular}


Tridelpina Purba S, Dianti Siboro T : Efektivitas Penerapan Penggunaan Laboratorium Riil Dalam Tatanan Pembelajaran Berbasis Masalah Terhadap Keterampilan Proses Sains Siswa Kelas XI SMA Negeri 6 Pematangsiantar

\begin{tabular}{|c|c|}
\hline $40-54$ & Rendah \\
\hline $0-39$ & Sangat Rendah \\
\hline
\end{tabular}

Tabel 4 Kriteria Pencapaian Kompetensi Keterampilan Proses Sains

\begin{tabular}{|c|c|}
\hline Rentang Nilai & Kriteria \\
\hline $86-100$ & Sangat Baik \\
\hline $71-85$ & Baik \\
\hline $56-70$ & Cukup \\
\hline $0-55$ & Kurang \\
\hline
\end{tabular}

\section{HASIL PENELITIAN}

Pelaksanaan pembelajaran di dalam kelas secara umum telah berlangsung sesuai dengan rencana pembelajaran yang telah ditetapkan. Penelitian tindakan kelas ini dilaksanakan dalam dua siklus. Setiap siklus terdiri dari tiga kali pertemuan, yaitu dua kali pertemuan untuk proses pembelajaran dan satu kali untuk pemberian tes.

Tabel 5 Skor Hasil Belajar Sisiwa pada Siklus I dan Siklus II

\begin{tabular}{|c|c|c|}
\hline \multirow{2}{*}{ Siklus } & \multicolumn{2}{|c|}{ Hasil Belajar Siswa } \\
\cline { 2 - 3 } & Rata-Rata & Kriteria \\
\hline Siklus I & 73,28 & Sedang \\
\hline Siklus II & 83,44 & Tinggi \\
\hline
\end{tabular}

Berdasarkan tabel hasil penelitian dari siklus diatas, diperoleh bahwa ketuntasan hasil belajar setelah diterapkan model pembelajaran berbasis masalah pada siklus I sebesar 73,44 dan dikategorikan sedang. Pada siklus II setelah diterapkan model pembelajaran berbasis masalah diperoleh ketuntasan hasil belajar siswa sebesar 83,44 dan dikategorikan tinggi.

Tabel 6 Hasil Observasi Keterampilan Proses Sains pada Siklus I dan Siklus II

\begin{tabular}{|c|c|c|}
\hline \multirow{2}{*}{ Siklus } & \multicolumn{2}{|c|}{ Hasil Belajar Siswa } \\
\cline { 2 - 3 } & Rata-Rata & Kriteria \\
\hline Siklus I & 70 & Cukup \\
\hline Siklus II & 82 & Baik \\
\hline
\end{tabular}

Berdasarkan tabel diatas diperoleh bahwa keterampilan proses sains siswa pada siklus I memiliki nilai rata-rata 70, sedangkan keterampilan proses sain siswa pada siklus II memiliki nilai rata-rata 82. Ini berrati keterampilan proses sains siswa pada siklus II lebih meningkat dari siklus ke I

\section{PEMBAHASAN:}

Keterampilan proses sains adalah keterampilan proses ilmiah yang digunakan untuk memperoleh pengetahuan dan mengembangkan konsep atau teori atau prinsip dalam kehidupan sehari-hari. Melalui penerapan model problem based learning berbasis laboratorium riil, menghadapkan siswa pada suatu masalah untuk memperoleh pengetahuan baru dan laboratorium rill merupakan tempat yang penting dimana pengetahuan baru dihasilkan dalam bentuk eksperimen. Pencapaian keterampilan proses sains yang diperoleh pada penelitian ini, berada dikategori "cukup" dan "baik". Untuk indikator mengamati, mengklasifikikasi, merencanakan percobaan dan berkomunikasi dikategorikan baik dan 
Tridelpina Purba S, Dianti Siboro T : Efektivitas Penerapan Penggunaan Laboratorium Riil Dalam Tatanan Pembelajaran Berbasis Masalah Terhadap Keterampilan Proses Sains Siswa Kelas XI SMA Negeri 6 Pematangsiantar

untuk merumuskan hipotesis dikategorikan sangat baik. Kemudian rata-rata peningkatan hasil belajar dengan menggunakan model pebelajaran berbasis masalah yang memiliki rentang perbedaan yang besar dari siklus I sampai siklus II dimana dapat dikategorikan dari sedang menjadi tinggi. Dari hasil penelitian di atas, dapat disimpulkan bahwa pembelajaran biologi dengan penerapan penggunaan laboratorium rill dalam tatanan model pembelajaran berbasis masalah mampu meningkatkan keterampilan proses sains siswa. pada kelas XI SMA Negeri 6 Pematangsiantar.

\section{KESIMPULAN}

Kesimpulan pada penelitian ini adalah :

Berdasarkan hasil penelitian diatas diperoleh bahwa ketuntasan hasil belajar pada siklus I sebesar 73,44 dan dikategorikan sedang. Pada siklus II setelah diterapkan model pembelajaran berbasis masalah diperoleh ketuntasan hasil belajar siswa sebesar 83,44 dan dikategorikan tinggi. Hasil penelitian tentang keterampilan proses sains siswa pada siklus I memiliki nilai rata-rata 70, sedangkan keterampilan proses sain siswa pada siklus II memiliki nilai rata-rata 82. Ini berrati keterampilan proses sains siswa pada siklus II lebih meningkat dari siklus ke I. Pencapaian keterampilan proses sains yang diperoleh pada penelitian ini, berada dikategori "cukup" dan "baik". Untuk indikator mengamati, mengklasifikikasi, merencanakan percobaan dan berkomunikasi dikategorikan baik dan untuk merumuskan hipotesis dikategorikan sangat baik. Kemudian rata-rata peningkatan hasil belajar dengan menggunakan model pebelajaran berbasis masalah yang memiliki rentang perbedaan yang besar dari siklus I sampai siklus II dimana dapat dikategorikan dari sedang menjadi tinggi. Dari hasil penelitian di atas, dapat disimpulkan bahwa pembelajaran biologi dengan penerapan penggunaan laboratorium rill dalam tatanan model pembelajaran berbasis masalah mampu meningkatkan keterampilan proses sains siswa pada kelas XI SMA Negeri 6 Pematangsiantar.

\section{DAFTAR PUSTAKA}

Adesoji, F. A. \& T. L. Ibraheem. 2009. Effects of Student Team Achievement Divisions Strategy and Mathematics Knowlegde on Learning Outcomes in Chemical Kinetics. The Journal Of International Social Research, 2(6) : 16-25. Anni, T. C. 2007. Psikologi Belajar. Semarang: UPT UNNES Press.

Abdul Majid. (2013). Strategi Pembelajaran. Bandung: PT Remaja Rosdakarya Agus Suprijono. (2009). Cooperative Learning. Yogyakarta: Pustaka Pelajar Arikunto, S. 2006. Prosedur Penelitian Pendekatan Suatu Praktek. Jakarta: PT Rineka Cipta. Arikunto, S. 2009. Dasar-Dasar Evaluasi Pendidikan. Jakarta : Bumi Aksara.

Arends, Richard I. (2008). Learning to Teach: Belajar untuk Mengajar. Penerjemah: Helly Prajitno S. \& Sri Mulyantini S. Yogyakarta: Pustaka Pelajar.

Dimyati \& Mudjiono. 2006. Belajar dan Pembelajaran. Jakarta: Rineka Cipta. Isjoni. 2011. Pembelajaran Kooperatif Meningkatkan Kecerdasan Komunikasi antar Peserta Didik. Yogjakarta : Pustaka Pelajar.

Mulyati. 2005. Psikologi Belajar.Yogyakarta: Penerbit Andi

\begin{tabular}{|l|l|l|l|}
\hline Accepted Date & Revised Date & Decided Date & Accepted to Publish \\
\hline 19 November 2020 & 22 November 2020 & 30 November 2020 & Ya \\
\hline
\end{tabular}

